\title{
RAINWATER MANAGEMENT IN THE URBAN LANDSCAPE OF WROCLAW IN TERMS OF ADAPTATION TO CLIMATE CHANGES
}

\author{
Katarzyna Tokarczyk-Dorociak ${ }^{1}$, Ewa Walter ${ }^{1}$, Katarzyna Kobierska² ${ }^{2}$ Robert Kołodyński ${ }^{2}$ \\ 1 Institute of Landscape Architecture, Wrocław University of Environmental and Life Sciences, Grunwaldzka 53, \\ 50-363 Wrocław, Poland \\ 2 Graduate of landscape architecture, Wroclaw University of Environmental and Life Sciences, Grunwaldzka 55, \\ 50-357 Wrocław, Poland \\ Corresponding author's e-mail: katarzyna.tokarczyk-dorociak@up.wroc.pl
}

Received: 2017.08 .07

Accepted: 2017.09.10

Published: 2017.11.01

\begin{abstract}
Modern city development requires increasing investments in so-called green and blue infrastructure. Water deficits and frequent droughts are a motivation for the introduction of economic water management and rainwater retention. Urban areas, which are often intensively developed and sealed, have lost their natural ability to retain rainwater. This is often the cause of urban floods that occur as a result of intense rainfall events, the intensity of which exceeds the capacity of urban drainage systems. These problems are caused by low surface and soil retention. These negative phenomena force us to take certain actions related to urban hydrology, such as determining catchments in urban areas and capturing rainwater. Town and city management must also take into account the functional and aesthetic aspects with the aim to improve the life quality of residents. Rainwater management on site of the rainfall allows to combine sustainable water management with the creation of places characterized by high aesthetic and functional value. The paper outlines the policy of the city of Wrocław with respect to rainwater management and presents the proposed solutions for a selected street, large-surface parking lot and a city square. Calculating the rainfall amount correctly and then preparing a land management design allows to use rainwater in creating attractive recreation areas.
\end{abstract}

Keywords: retention, rainwater, urban areas

\section{INTRODUCTION}

Rainwater management in urban areas is currently a highly important and intensely developed issue, both in research and in practice. The threats connected with global water deficit and the directions of actions to eliminate them were first formulated in Agenda 21 - a document developed during the Earth Summit in Rio de Janeiro in 1992. Rainwater management, in particular enabling rainwater retention and infiltration into the soil in strongly urbanised areas, have been considered as one of the priorities of sustainable water management. New methods and devices, especially integrated systems that constitute an alternative for the traditional rainwater drainage systems, have become a standard in numerous
European countries and the USA, where they have considerably influenced the development of environmental engineering, construction, architecture and town planning or landscape architecture. At the end of the 1990s and at the beginning of the $21^{\text {st }}$ century, numerous town-planning and landscaping projects were created with the aim to introduce a new way of rainwater management. Today, these investments are considered the first, showcase examples of sustainable drainage systems that are integrated with the whole complex. These are:

- the Kronsberg residential district constructed for the EXPO 2000 exhibition (Hannover, Germany),

- the Potsdamer Platz commercial and service facilities in the city centre (Berlin, Germany), 
- the university campus with a recreated network of streams and flood terraces (Helsinki, Finland),

- the residential complex with an elaborate rainwater management system in green areas (Oulu, Finland),

- the Küppersbusch residential estate (Gelsenkirchen, Germany) - a project constructed for the IBA Emscher Park exhibition,

- the Bo01 residential and service complex (Malmo, Sweden),

- Millennium Village residential estate (London, UK),

- Natural Drainage System (Seattle, the United States).

Some of them were described as early as in 2004 by the Finnish landscape architect Jukka Jormola (Jormola 2004) as experimental, widely discussed projects. Jormola focused mainly on the protection and restoration of natural water habitats in the urban environment or creating artificial systems modelled on natural patterns.

The development of environmentally-friendly rainwater management in terms of landscape architecture was also influenced by the German landscape architect Herbert Dreiseitl, who, in his book entitled „Planning, Building and Designing with Waterscape" shows own landscape design projects that use sustainable drainage systems or single devices for rainwater management (Dreiseitl, Grau, Ludwig 2001). Herbert Dreiseitl is currently one of the leading designers of sustainable rainwater management systems as part of the water strategies of cities and his projects in urban hydrology have been implemented throughout the world for the last 35 years.

Main American authors of rainwater management solutions include Daniel Winterbottom (Winterbottom 2001) and Patricia W. Waterfall (Waterfall 1998). As far as landscape design is concerned, the paper by Christer Göransson describes the aesthetic aspects of rainwater management systems planning in cities, based on the example of Sweden (Göransson 1998).

Later on, there have been so many publications on the subject, both in Europe and throughout the world that it would be difficult to attempt to order them according to a chronology or hierarchy.

In Poland, a new approach to rainwater management was initiated by Alina NowakowskaBłaszczyk from the Warsaw University of Technology, who, at the turn of the 1980s and the 1990 s, analysed the rainwater runoff in terms of the possibility of its direct infiltration into soil. Long-term research constituted a basis for Nowakowska-Błaszczyk and her team to introduce a new approach to the drainage of rainwater from sealed areas, which was then implemented in residential estates in Warsaw, including Wilga VII and the Floryda Estate (Nowakowska-Błaszczyk 1995). One might say that this was the first step towards the "demythologisation" of rainwater runoff, which, in the light of Polish legislation, is treated as wastewater that must be discharged by sealed drainage systems.

Since that time, the interest in new methods of rainwater management in Poland has increased, resulting in a development of research that proved the efficiency of such methods on the one hand and dispelled the myth that rainwater is a "threat" for the environment on the other. It is worth mentioning that the first Polish landscape architect, Przemysław Wolski from the Warsaw University of Life Sciences, started to introduce new alternatives to rainwater drainage systems in some of his designs. Many researchers and practitioners based their works on the existing studies and methods as well as the projects realised in Europe or in the USA. The developing studies were also inspired by the only manual for engineers available in Polish language, i.e. the "New methods of rainwater disposal" (Geiger, Dreiseitl 1999).

At the beginning of the $21^{\text {st }}$ century, the subject of environmentally-friendly rainwater management became more widely discussed, mainly in the technological context, i.e. the application of new, more sustainable filtration or retention equipment (Suligowski, Gudelis-Taraszkiewicz 2003). Increasing attention was paid to the specific influence of so-called small-scale retention facilities on the water relations in urban areas. The subject turned out to be so important that numerous seminars, conferences and debates were starting to be organised specifically to discuss the most effective and environmentally-friendly methods of rainwater management that allow to normalise the water balance in urban areas. However, some time had elapsed before the discussion on whole systems of sustainable rainwater management started, which also emphasised the visual aspects that are important from the point of view of designing urban public spaces.

Currently, both in Poland and throughout the world, the issue of rainwater management is treated as a major element of sustainable water resources management on the municipal, regional and national scale, in holistic, integrated 
terms (Szewrański, Kazak, Szkaradkiewicz, Sasik 2015). The basis for actions in Europe is provided, among others, by the Framework Water Directive that obliges EU Member States to implement actions aimed at the rational use of water resources, which should mitigate the effects of water balance disturbances, especially in the urban areas. Another document laying out the framework for action is the White Paper on Adaptation to Climate Change, which clearly emphasises the importance of adapting cities to climate changes. Future scenarios demonstrate unambiguously that the climate will become warmer and the amount of available water will decrease (data of the Intergovernmental Panel on Climate Change, IPCC). Additionally, the intensity of torrential rain events, which have already become the main reason for floods in cities, will increase. The images below (Fig. 1-4) illustrate the problems that occur in Wrocław after heavy rain. Although these are mainly short-term urban floods, they have major consequences for the residents and the economy.

Proper adaptation of cities to climate change involves the actions aimed not only at the prevention of negative effects of floods and flooding but also at predicting the consequences of droughts, which may affect the quality of life of residents very seriously due to changes in the distribution of precipitation and to the prognosed increase in temperature.

Drapella-Hermansdorfes (2016) points out that, due to the current water management problems, the main tasks of the authorities of Wrockaw - in this respect - should be aimed, among others, at: slowing down the water runoff, building barrages and supporting small-scale retention in the city. The author recommends developing local standards for rainwater management on site in Wrocław.

Similar rainwater management strategies are used in numerous European cities (the most frequently mentioned example is Copenhagen, where a comprehensive strategy was devised) and developed by some other Polish cities. In Poland, analytic and design works are currently in progress in Warsaw. The city ordered a study of the characteristics and an evaluation of the functioning of its hydrographic system, focusing on the drainage system in the area of the capital city of Warsaw, along with the recommendations for the spatial development conditions and directions study. The study is the first step to create a mu- nicipal hydrology management system (including rainwater management). Rainwater management programmes are also implemented in Lodz as part of the "Blue and Green Lodz" concept and in Radom under the Life project "Adaptation to climate changes through sustainable water management in the municipal area of Radom".

In practice, the perfect design and technology solutions that enable sustainable rainwater management already exist. The currently developed land development plans should definitely take into account the management of rainwater by retaining it and employing to shape the space. Even more so, because for centuries water in landscape

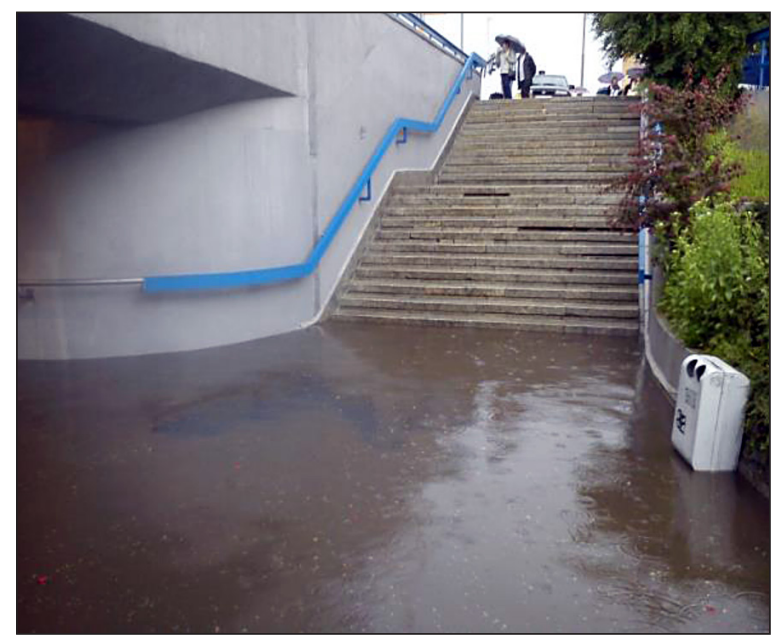

Fig. 1. Local flooding in Legnicka street near Strzegomski square (July 2014). Photo: R. Kołodyński

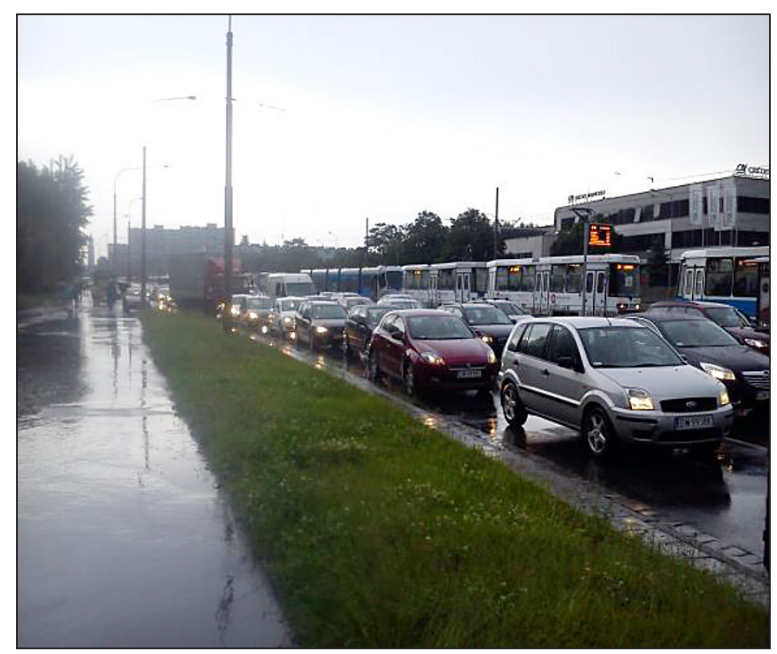

Fig. 2. Traffic jam on one of the main arterial roads of Wrocław. Both car and tramway traffic were blocked by torrential rain (July 2014).

Photo: R. Kołodyński 


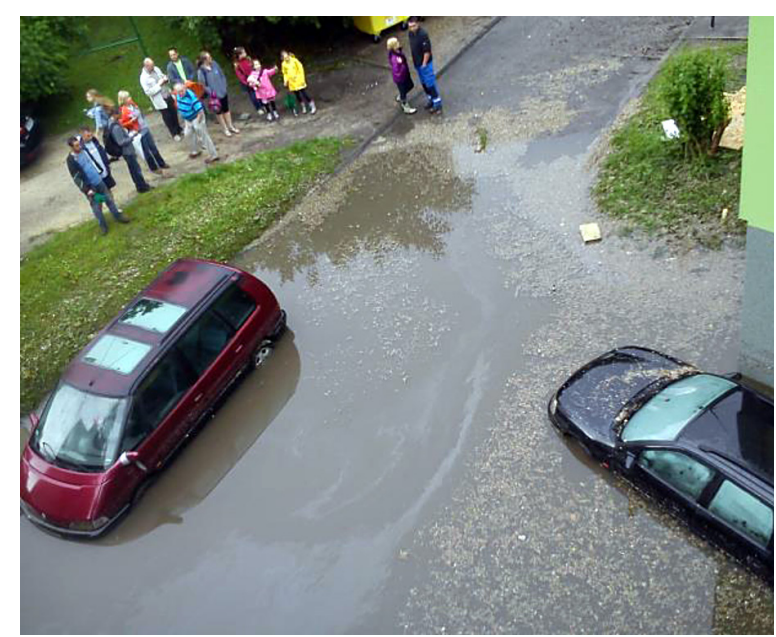

Fig. 3. An overflowing drainage well during intense rainfall in Ścinawska street.

Photo: R. Kołodyński

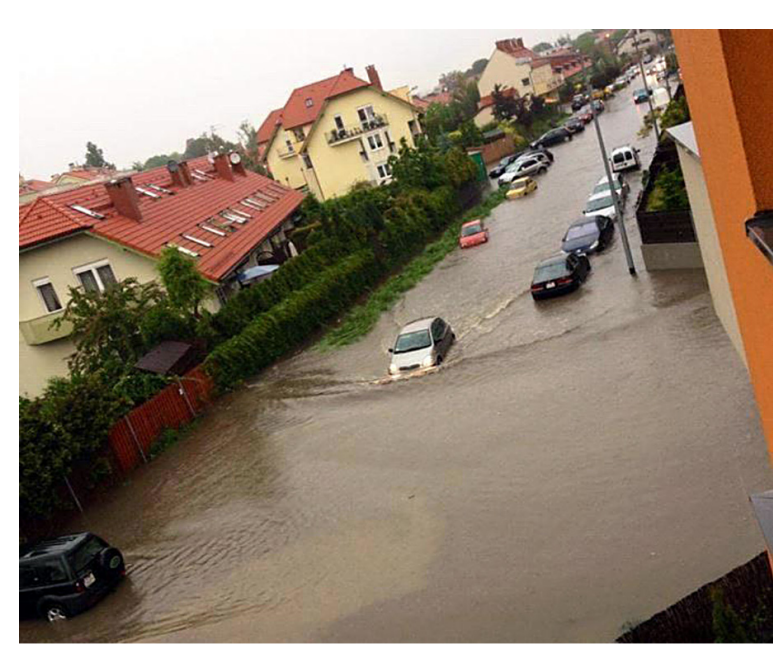

Fig. 4. Słonimska street, Muchobór Wielki Photo: Anna Maria K.

has improved its quality by positively influencing all landscape uses and increasing biodiversity. At present, one more essential aspect is raised, which is the influence on the microclimate by lowering air temperature. As a result, in hot weather, air temperature in the proximity of water may be lower by even $2-3{ }^{\circ} \mathrm{C}$.

\section{CLIMATE CONDITIONS IN WROC ŁAW}

Wrocław is located in the moderate latitudes, so it is characterised by a transitional climate. Contrasting oceanic and continental influences result in high changeability. The main element of the landscape in Wrocław is the Oder River, which constitutes an axis that divides the city into the eastern and western parts and is, at the same time, an important ecological corridor of the town. Its presence influences the climate considerably by causing frequent fogs and high air moisture content. In Wrocław, winds from the western and southern sectors are dominant, as the city is located between the humid climate of the Atlantic Ocean and much drier climate of the Asian continent (Dubicki A., Dubicka M. Szymanowski M., 2002).

Precipitation characteristics were based on the data published in 2015 by the Institute of Meteorology and Water Management in Wrocław, while the characteristics of other meteorological factors are based on the data presented in reports and literature.

\section{TEMPERATURE}

Average temperatures in Wrocław range from $-0.4^{\circ} \mathrm{C}$ (January) to $18.8^{\circ} \mathrm{C}$ (July). The annual average is $9^{\circ} \mathrm{C}$. Wrockaw belongs to those cities situated in lowland areas that are characterised by the lowest annual temperature amplitudes $\left(19.2^{\circ} \mathrm{C}\right)$. The highest fluctuations, ranging from $+4.4^{\circ} \mathrm{C}$ to $11.2^{\circ} \mathrm{C}$ are noted in the winter months. The city enjoys one of the longest vegetation periods that lasts approx. 226 days (temperature $\geq 5^{\circ} \mathrm{C}$ ). However, sunny days are rather rare - approx. 27; while there are approx. 203 cloudy days per year. The warmest thermal season in Wrockaw is, obviously, the summer (approx. $15^{\circ} \mathrm{C}$ ), followed closely by autumn with temperatures from $5.1-14.9^{\circ} \mathrm{C}$. Early spring and forewinter are characterised by the same temperature ranges, i.e. 0.1 to $5.0^{\circ} \mathrm{C}$, while winter is characterized by constant temperatures $\leq 0^{\circ} \mathrm{C}$ (Dubicki et al. 2002).

\section{PRECIPITATION}

Wroclaw is one of the cities with low precipitation, due to the fact that it is located in the axis of the Silesian Lowland. The average total annual precipitation from the long-term period 1995-2014 was $569.75 \mathrm{~mm}$ (according to data obtained from IMGW), and the number of rainy days per year is approx. 167. The precipitation in the long-term period specified above showed relatively high fluctuations: from $432 \mathrm{~mm}$ (year 2003 ) to $735 \mathrm{~mm}$ (year 2009). The minimum daily average was $1.18 \mathrm{~mm}$, while the maximum was 
$2.01 \mathrm{~mm}$. The mean daily precipitation from the whole period was $1.58 \mathrm{~mm}$.

The analysis of Fig. 5 showing the total annual precipitation in Wrocław demonstrates an increasing trend in total precipitation in the years 1995-2014. The highest total precipitation was noted in 2009, while the lowest - in 2003.

The research conducted by Dubicki et al. (2002) shows that the amount of precipitation is influenced by the spatial management. According to Dubicki et al. (2002), the differences in precipitation in individual districts of Wrocław can be very high. During a torrential rain event that lasted for several hours on June $6^{\text {th }}, 2017$, extremely high differences in the amount of precipitation were noted in specific districts, for example: Biskupin - $47.4 \mathrm{~mm}$, the Botanical Garden - $109.0 \mathrm{~mm}$, Strachowice $-47.8 \mathrm{~mm}$, Stabłowice - 63.9 mm, Psie Pole - $48.1 \mathrm{~mm}$, Oporów - 34.6 $\mathrm{mm}$, Karłowice $-55.3 \mathrm{~mm}$, Tarnogaj $-63.2 \mathrm{~mm}$. The same study demonstrated that much higher precipitation (by approx. 11\%) occurs in the districts characterised by dense development than in peripheral areas.

On the other hand, the study by Schmuck (1967) demonstrated that the "privileged" districts of Wrocław, i.e. those characterised by the highest precipitation, are the Old Town, City Centre, Krzyki and Karłowice, which shows that the axis of highest precipitation is oriented from NE to SW. Much lower precipitation was noted in the eastern parts of the city (Biskupin, Swojec), as well as the western districts.

\section{SPATIAL MANAGEMENT AND THE RAINWATER ISSUE IN WROC ŁAW}

Currently, the green and blue infrastructure is important not only because of the environmental protection, but also due to its proper influence on the spatial management of areas, recreational values as well as the economic effects connected with using it (Ladysz, 2014). Rainwater potential has extremely high potential for shaping spaces that are friendly to humans and to the environment. It will also reduce the load of drainage networks and, in a long-term perspective it will enable to save the funds spent on wastewater treatment.

The environmental economics theory proves that market instruments are more efficient than administrative and legal ones (Fiedor B., Czaja S., Graczyk A., Jakubczyk Z., 2001). Rainwater management is a perfect example. On the one hand, discharging rainwater to drainage systems generates costs, while on the other hand, sealing soil results in reduced water retention, and thus the loss of bioretention (which can also be calculated in terms of market value). Introducing rainwater fees (so-called rain tax) allows the property owners to decide whether to discharge rainwater to drainage systems (and pay the fees) or to manage it on their property by enabling water retention on site of the rainfall.

In the cities exposed to the risk of torrential rains, the introduction of such solutions allows excess water in permeable areas to infiltrate into

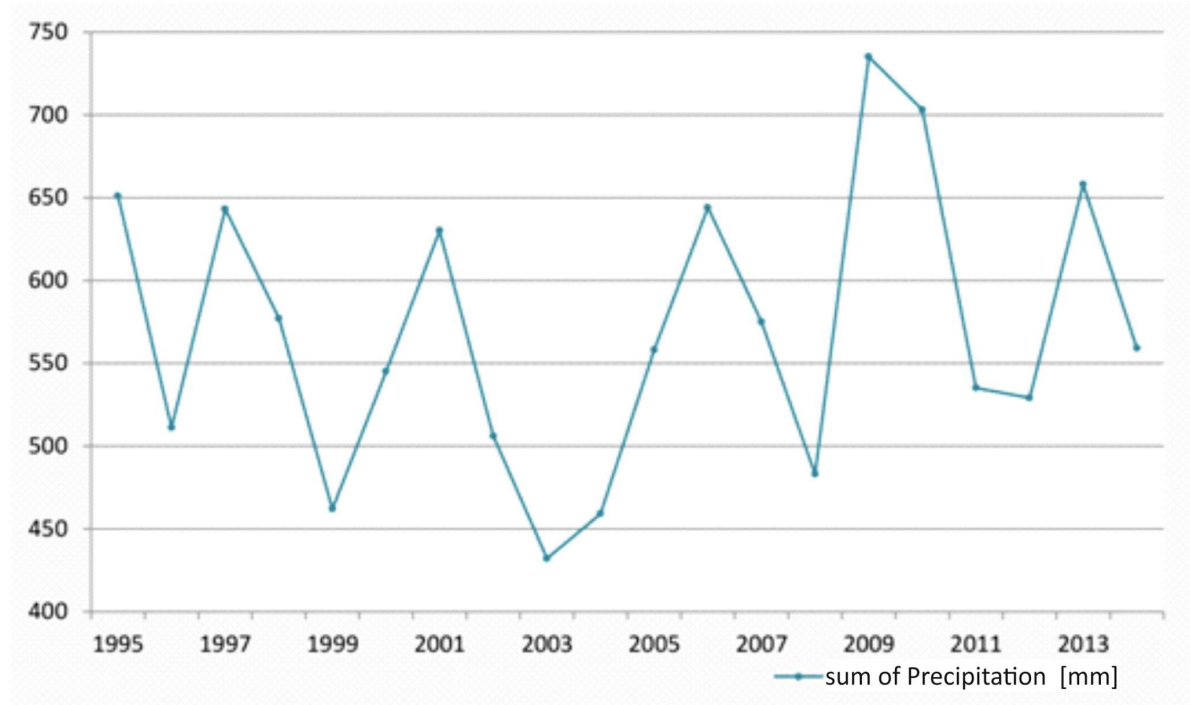

Fig. 5. Total annual precipitation in Wrocław in the years 1995-2014 (the year 2014 is incomplete - until November) [Kobierska 2015] 
the ground instead of developing the flood-protection infrastructure (Ladysz, 2014).

In 2011, the Municipal Council of Wrocław adopted a resolution (Resolution No. XVIII/349/11 $)^{1}$ on fees for discharging rainwater and snowmelt to drainage facilities in the territory of the Wrocław Municipality. Pursuant to the Resolution, inhabitants of Wrocław have been paying the rain tax since 2012. The fee for collective discharge of rainwater and snowmelt to drainage systems is determined annually. Currently, it amounts to PLN $1.47 / \mathrm{m}^{3}$. According to Burszta-Adamiak (2014), the introduction of this fee caused numerous debates and dissatisfaction among property owners. Some of these disputes result from the fact that the city failed to conduct an informational campaign to explain to residents why they are obliged to pay a fee for rainwater discharged from their properties. It is necessary to provide the technical and financial support for the realisation of investments aimed at rainwater management. As international experience has confirmed, this will be a milestone in the introduction and acceptance of fees. It will also contribute to increased investments in blue and green infrastructure for the purposes of e.g. municipal hydrology. The fees for discharging rainwater should be used to finance the investments related to rainwater management. Environmental fees and administrative fines are the main source of financing environmentally-friendly investments, including those connected with rainwater management. It is necessary to ensure the funding for the investments connected with rainwater, because the funds allocated to them so far have been insufficient. It is also not permitted by law to use cross-subsidies, i.e. to cover the costs of discharge and treatment of rainwater from the sales of water or from the fees for discharge and treatment of municipal and household wastewater (Burszta-Adamiak, 2014).

The legal and administrative solution that supports a sustainable rainwater management are the provisions of the spatial development conditions and directions study of the municipality as well as the local spatial development plans.

The currently binding spatial development conditions and directions study for Wrockaw (Resolution of the Municipal Council of Wrocław No. L/1467/10 of May 20, 2010) mentions the threats connected with rainwater in conditions,

\footnotetext{
${ }^{1}$ http://edzienniki.duw.pl/duw/WDU_D/2012/353/Akt.pdf
}

by pointing out the fact that the city is exposed to floods: "Wrockaw, being situated in the Oder Valley and in the area of confluence of four of its tributaries, is exposed to frequent floods: resulting from rainfall in summer and autumn and from snowmelt in winter and spring."

As far as the water protection is concerned, the study identified the issue of water pollution as a result of a low amount of rainwater, including those polluted with petroleum products subjected to treatment.

In the Directions section, the study provides the following recommendation: "In order to prevent overdrying of the developed area and to reduce rainwater runoff, attempts should be taken, as far as possible, to retain non-polluted rainwater in developed areas, among others by means of constructing water reservoirs and using rainwater to irrigate green areas".

The recommendations include a suggested attempt to coordinate the rainwater management, which involves:

- reducing the rainwater runoff coefficient,

- retaining rainwater, including the green areas; if necessary, the ditches that collect rainwater should be eliminated,

- specifying alternative rainwater collecting facilities,

- modernising the collecting facilities designed for introducing additional amounts of rainwater,

- draining areas adjacent to roads by means of rainwater drainage systems constructed in roads.

The Municipal Water and Sewerage Company in Wrocław publishes a current water and sewage map in the Wrocław Spatial Information System that contains the information about the following: non-runoff tanks and their catchments, water and wastewater quality monitoring stations, water quality zones, active and inactive sections of water supply networks and sewage networks, divided into rainwater drainage, general sewage, sanitary sewage and others.

The fact that rainwater management issues have been considered in the planning documents demonstrates that the authorities are aware of their importance and the need to take action with respect to these issues. Unfortunately, the spatial development conditions and directions study of a municipality is not binding. It must only be tak- 
en into account while creating new local spatial development plans.

Currently, the works related to the development of green infrastructure in Wrocław are in progress. The "Design for the optimum green infrastructure arrangement in the area of the Wrocław Functional Area" has been developed (Niedźwiecka-Filipiak et al., 2016). The works on the new spatial development conditions and directions study (resolution of the Municipal Council of Wrocław No. LXI/1553/14 of July 10, 2014 on the commencement of preparing the new spatial development conditions and directions study for Wrocław) have started. The draft of the new study assigns priority to the sustainable rainwater management, which means rainwater management on site of the rainfall or, after preliminary treatment, discharging rainwater to another collecting reservoir (such as a pond, ditch or the soil). The main aim of water management in Wrockaw is to manage water in such way that will improve the environmental conditions in the city and the quality of life of its inhabitants.

The most recent document that deals with the issue of rainwater in Wrocław is the Regulation No. 6541/17 of the President of Wrocław of March 17, 2017 on rainwater management in Wrocław. It contains the principle of rainwater management on site of occurrence and gradual release and delaying the runoff that is impossible to be managed completely on site of the rainfall ( $\S 1.1$ ). Since the Regulation became effective, the principle has become the main recommendation for spatial planning in Wrocław and for municipal investments. By virtue of the provisions of the Regulation, the Municipal Rainwater Management System was created, consisting of: rainwater drainage network with equipment, general drainage system with equipment; reservoirs and other facilities for retention and infiltration purposes, including ditches; small ponds and reservoirs connected with other facilities and regulating the water relations; rainwater pumping stations and general wastewater pumping stations. The system is supervised by the Municipal Water and Sewerage Company in Wrocław, while the Municipal Board of Green Areas was obliged to transfer the elements belonging to the rainwater management system to the first authority. An important assumption included in the said Regulation is the collection and distribution of data necessary to shape the water management on site of rainfall in the Spatial Information System in Wrocław. The collected information will support the investment design process in compliance with $\S 1$ item 1 of the quoted Regulation.

Additionally, newly created documents should absolutely contain the requirements concerning rainwater management on site of rainfall for newly constructed and renovated municipal investments. The Regulation of the President obliges the Office for the Development of Wrocław to prepare changes to be introduced to the study of land use conditions and directions as well as the Architecture and Construction Department to take the provisions of the Regulation into account in its decisions on land development and management conditions. Another important obligation has been imposed on the municipal investments (newly constructed, renovated and rebuilt ones), which will have to consider the rainwater management. This will be realised by means of the requirement for the Description of the Object of Contract and the information about the conditions for connection to the rainwater drainage system to be approved by the Municipal Engineering Department.

The city of Wrocław has filed an application to the European Commission for the award of European Green Capital in 2019. In this competition, cities are evaluated in terms of 12 indicators, including: local contribution to the prevention of climate change, municipal transport management, urban green areas, combating noise, waste generation and management, environmental protection and biodiversity, air quality, water consumption, wastewater treatment, eco-innovations and permanent employment, environment management on the local administration level and energy efficiency.

The combination of the recommendations included in the study with the fee for rainwater discharge as well as the introduction of new requirements for municipal hydrology outlined in the Regulation of the President No. 6541/17 should contribute to the introduction of new, much needed solutions. The interest of the authorities of Wrocław in pro-environmental activities is also manifested in their attempts to receive the European Green Capital award, which pays much attention to adapting to climate changes, eco-innovations and the quality of life of residents. 


\section{THE NEED FOR NEW SOLUTIONS}

Rainwater management in urban areas should be based on case-specific assumptions that will perform several functions at the same time. First of all, they will allow to retain water on site of rainfall, thus reducing the amount of water flowing out of the catchment, but at the same time they will improve the life quality of inhabitants by creating aesthetic, human-friendly spaces. Most of the investments in the municipal hydrology realised in recent years involved not only a modern approach to rainwater, but also spatial design to create spaces that foster biodiversity and satisfy human needs.

The illustrations below present the drawings and visualisations of certain design solutions developed for the city of Wrockaw that demonstrate how to design areas taking into account the need to manage rainwater. The need for economic water management and for anti-flood protection demonstrates that all newly constructed investments should involve rainwater management on site of the rainfall. If used properly, rainwater will improve the quality of space. Wagner and Zalewski (2009) proved that the application of eco-hydrology as well as blue and green infrastructure enables to achieve high quality of urban environment and high quality of life of the inhabitants at very low costs.

The most important urban areas where rainwater management activities should be introduced as a priority are the areas adjacent to streets and large parking lots. Figure 6 presents an example of rainwater collection in a parking lot of a large supermarket, which might become a model for other, similar areas. The introduction of different elevation levels in the parking lot allows the water to flow down and fill a single, designated area. As a result, the remaining area is not exposed to flooding and proper management, which makes the parking lot much more attractive.

The application of similar solutions should be obligatory during the reconstruction, development and construction of new roads. The image below (Fig. 7) presents a proposed solution to be applied to ul. Legnicka in Wrocław. The design involves water runoff and collection in bioretention basins, which will protect the area against flooding and enable the removal of petroleum products from the rainwater flowing in from the communication areas and to retain it on site of rainfall.

Other essential investments that should be introduced by the city include the implementation of eco-innovations during renovation works in squares and spaces managed by the municipal authorities. The illustration below shows a concept of the development of the Piłsudski Square created in an MSc thesis that received an award in the Magnolia competition. The Piłsudski Square is the main square of the Karłowice district located in the northern part of the city. It used to be the main town square. The area is separated by 3 main streets (al. J. Kasprowicza, al. T. BoyaŻeleńskiego and ul. W. Berenta) which give it a triangular shape. Such an arrangement resulted in a space of a simple yet interesting form, which distinguishes it from the rest of the surrounding urban tissue. The square is surrounded by low, 2-3 storey townhouses, comprising residential multifamily houses, with service premises located on the ground floors along with such public institutions as: the Police Station Wrocław Psie Pole and the former Agora Cultural Centre. Karłowice are located approx. $6 \mathrm{~km}$ from Wrocław city centre, which means that the district is rather peripheral. Thus, it is very important to restore the former function of the market square to create a local centre supporting the cultural development of local residents. The square is currently in a poor state of repair and requires renovation (Fig. 8).

The design process took into account the results of public consultations conducted in June 2013 by the Polish Architects Association, which clearly demonstrated the need to eliminate parking lots, give some order to the space, introduce cultural functions (a gallery, and a cultural centre) and recreational facilities (a playground and a fountain). The conclusions of the consultations and the results of inventory and field analyses constituted the basis for the development of the concept. The submitted proposal of spatial management includes certain innovative solutions related to the municipal hydrology. The residents' expectations concerning the introduction of a water-based element were combined with rainwater retention. The design of the reservoir took into account the mean precipitation in Wrocław (based on the data obtained from the National Meteorology and Water Management Institute). The area from which rainwater would be collected was determined (roof surfaces and designed impermeable surfaces). Then, the capacity of the water reservoir was calculated, considering the volume of rainwater available during rainfall events of various intensity. Sub-catchments were defined in the analysed area (Fig. 9), considering various types of paving and terrain formation.

Rainwater will be collected from the roof surfaces (with use of gutters and water supply channels) and from impermeable surfaces that will be constructed on the square after modernisation. The simplified direction of rainwa- 


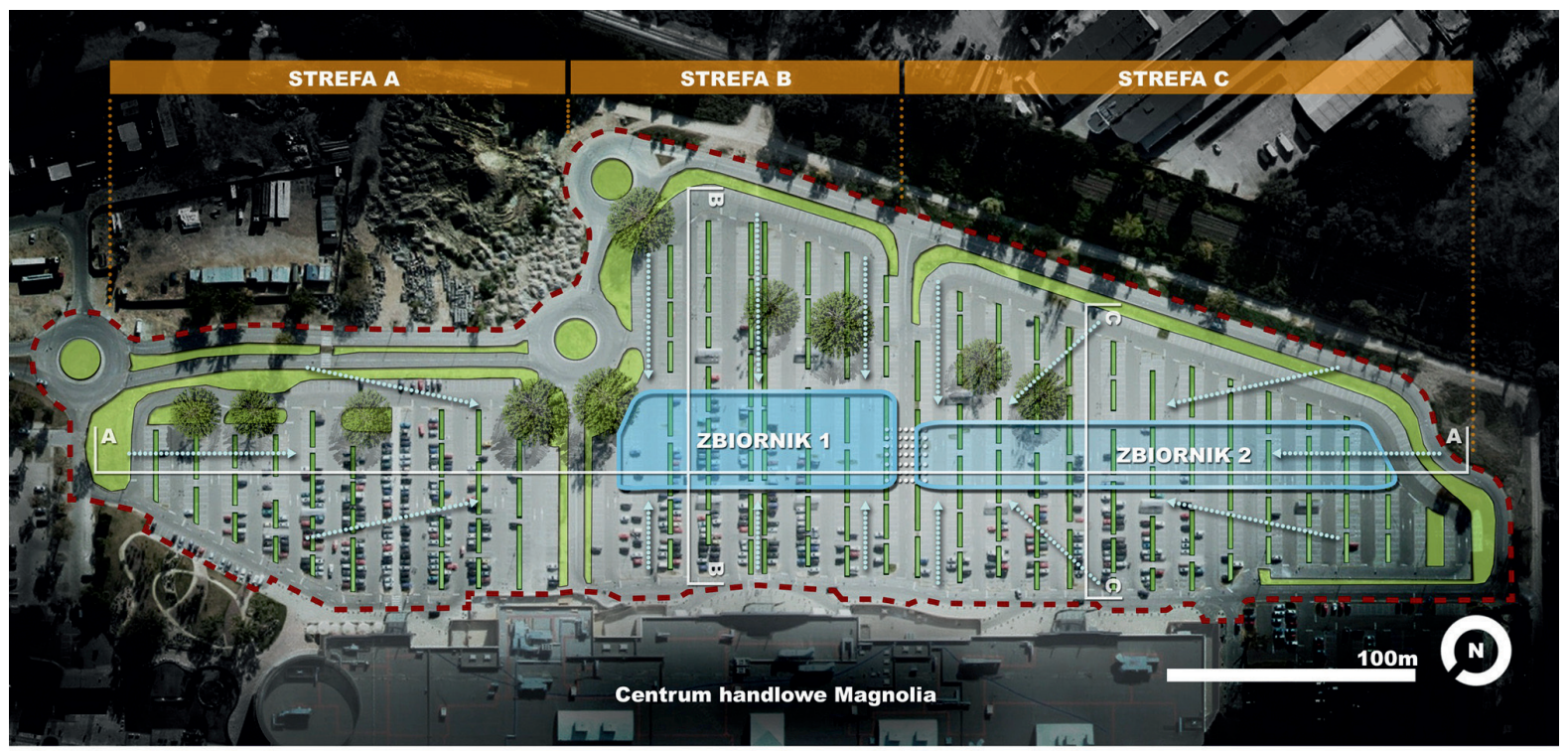

\section{LEGENDA}

\begin{tabular}{|c|c|c|c|}
\hline 다의 & Border of the study & 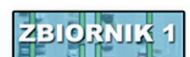 & Deeper retention reservoirs \\
\hline 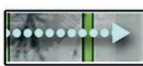 & General water runoff direction & 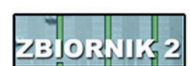 & Shallow retention reservoir \\
\hline & $\begin{array}{l}\text { Parking spots with semi- } \\
\text { permeable Surface, separated } \\
\text { by bioretention basin }\end{array}$ & & Trees \\
\hline & $\begin{array}{l}\text { Pedestrian walkways across } \\
\text { bioretention basin }\end{array}$ & $\overline{3}$ & Cross-section lines \\
\hline & Raingardens & STREFA & $\begin{array}{l}\text { Zones of various inclinations of } \\
\text { parking spaces }\end{array}$ \\
\hline FES & $\begin{array}{l}\text { Connection between retention } \\
\text { reservoirs }\end{array}$ & & \\
\hline
\end{tabular}

Fig. 6. Proposed rainwater management programme in the parking lot near a supermarket [Kołodyński 2015]

ter runoff and collection for part of the square is presented in Fig. 10.

The main underlying assumption for the development concept is the sustainable management of rainwater located within the area. However, it is equally important for the proposed solutions to be functional and to bring out the nature of the location. The introduction of a three-level water reservoir into the Piłsudski Square (Fig. 11 and 12) accentuates the atmosphere of a market square. This reservoir is the main element of the rainwater collecting system. It collects the water supplied through underground and partly surface channels from roofs and impermeable surfaces. It was designed taking into account varied precipitation conditions, so that it will remain attrac- tive both during the drought and intense rainfall periods. During long-term droughts it will be possible to fill the reservoir (e.g. one part of it) with tap water, enabling it can perform its function and mitigate climate change effects connected with the occurrence of the periods with high temperatures. The presence of the water reservoir will have a beneficial influence on the character of the site and improve the comfort of its users (Jawecki, 2004; Burda 2010).

The introduction of the proposed design solutions will allow to use the reservoir also in winter. When the water freezes, the reservoir may play the role of an ice-skating rink, or it may be used to store the snow removed from streets and pavements (Fig. 12). 


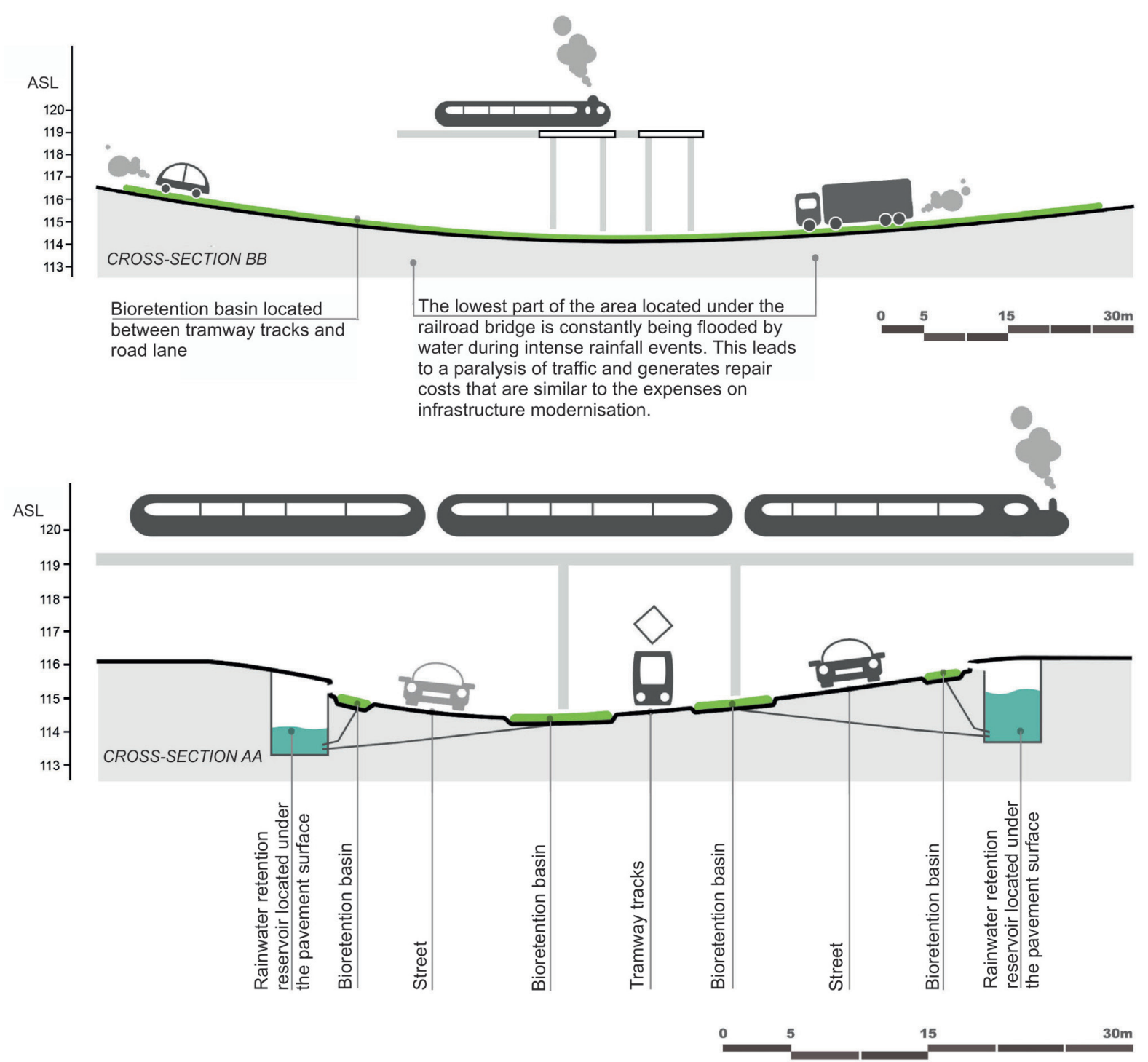

Fig. 7. Sample proposed bioretention basin at Legnicka Street in Wrocław [Kołodyński 2015]

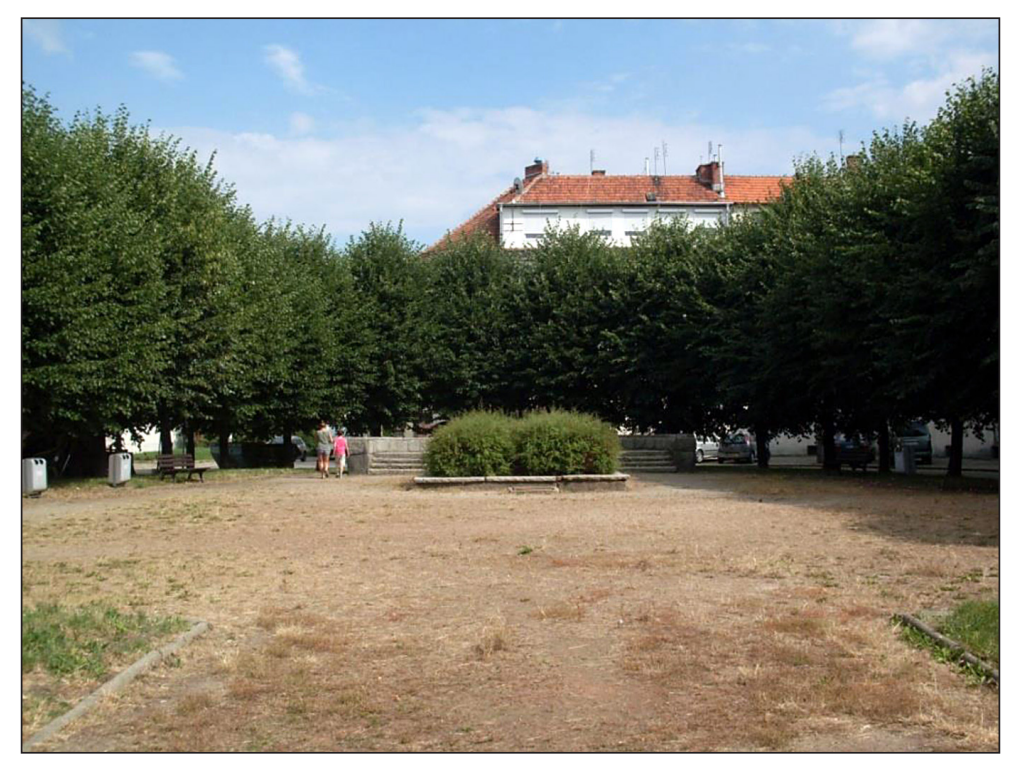

Fig. 8. View of the square surrounded by linden and fragments of the old fountain (photo K. Kobierska) 


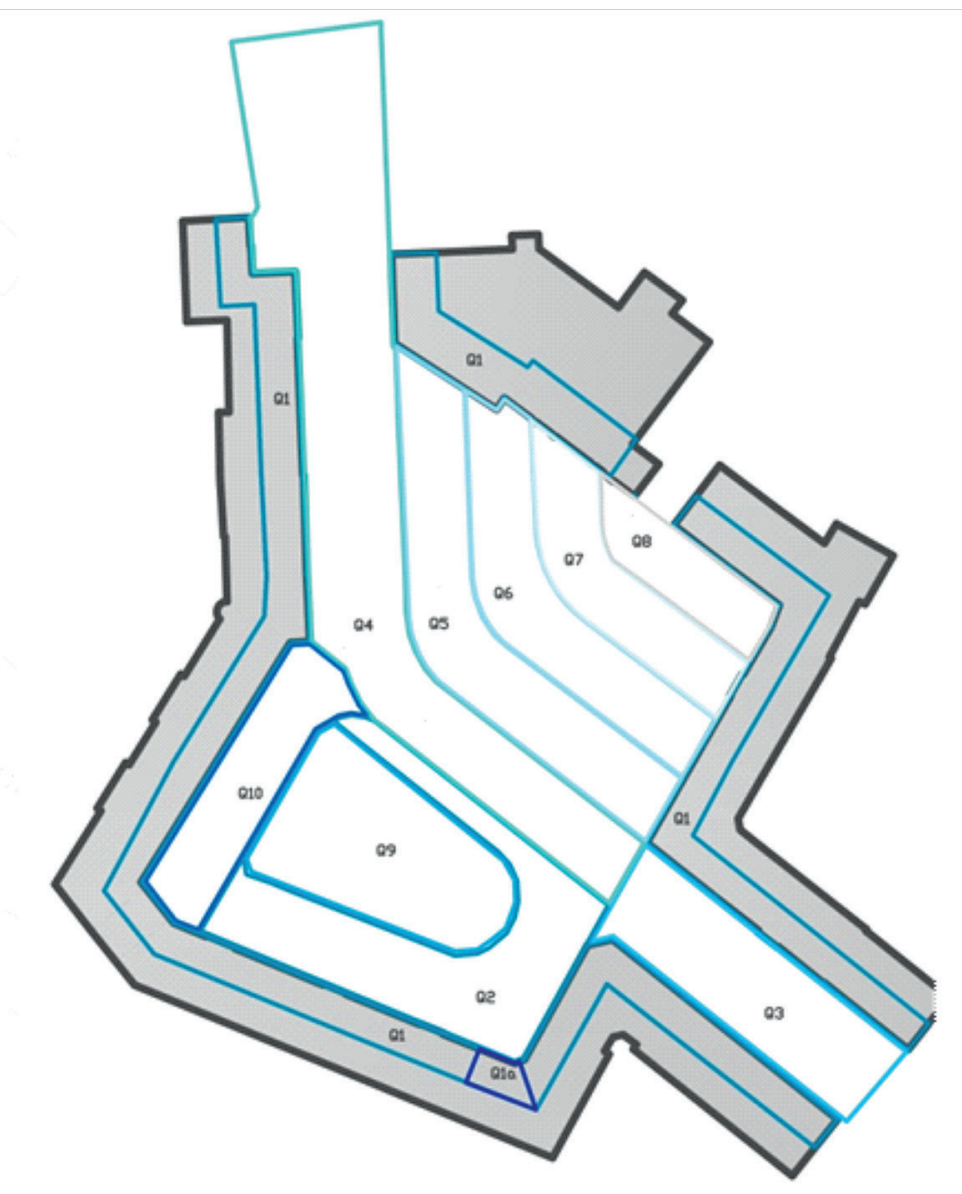

$\bigoplus$ DIAGRAM - runoff surfaces $(\mathrm{Q} 1, \mathrm{Q} 2 \ldots \mathrm{Q} 10)$

Fig. 9. Diagram illustrating the surfaces of sub-catchments determined in the analysed area [Kobierska 2015]

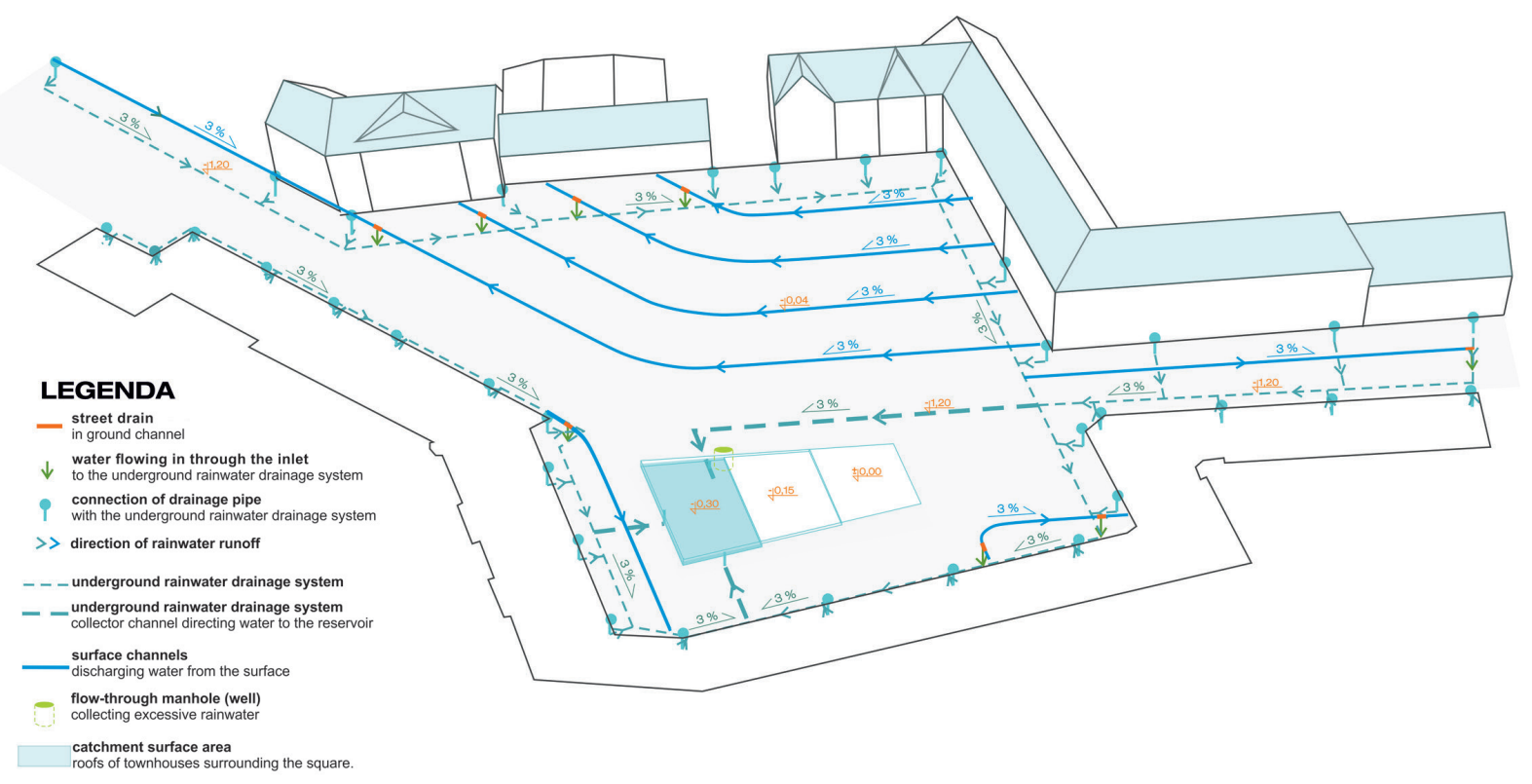

Fig. 10. Simplified axonometric diagram of rainwater runoff [Kobierska 2015] 


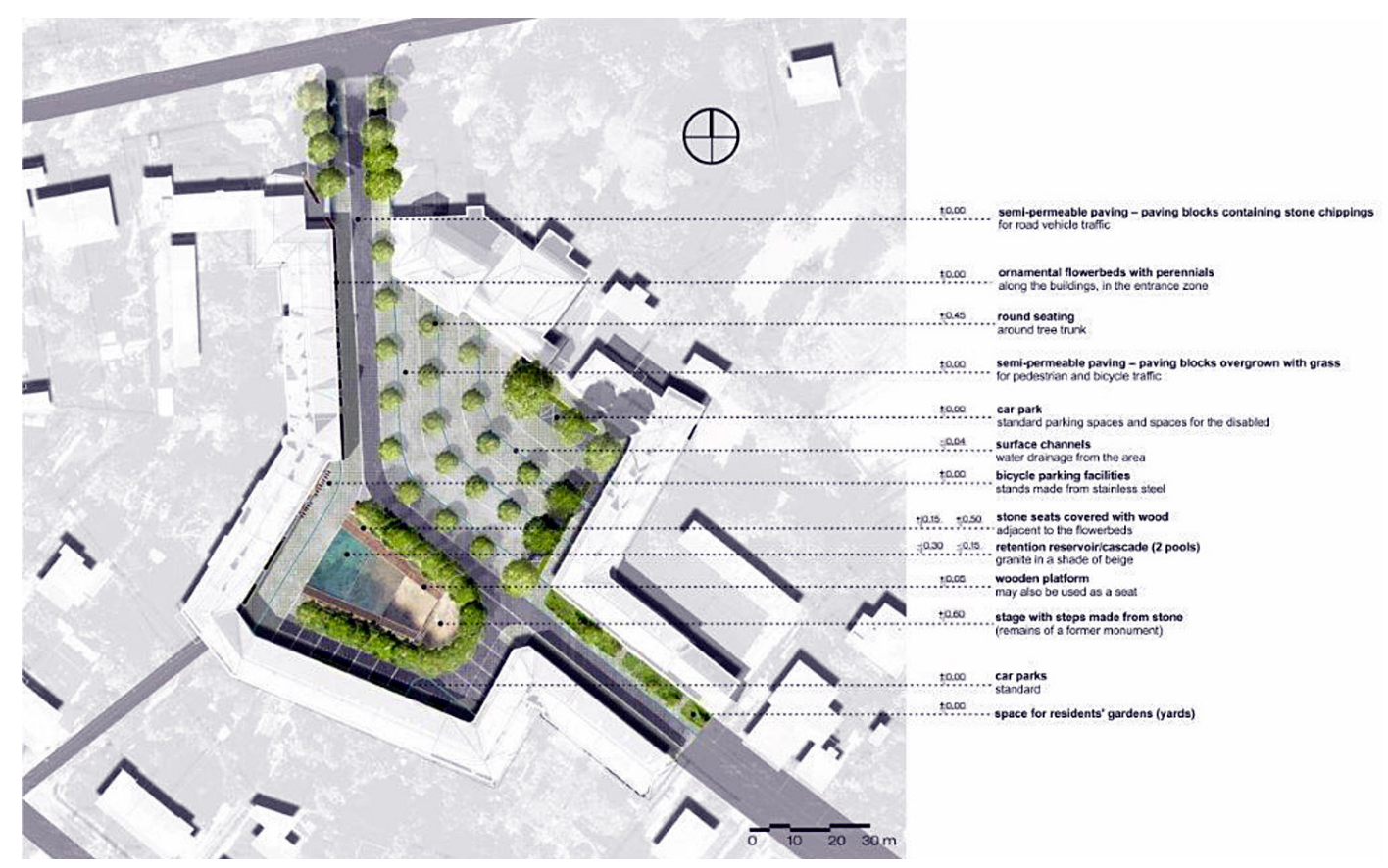

Fig. 11. Designed square with a three-level water reservoir (view from above) [Kobierska 2015]

a)

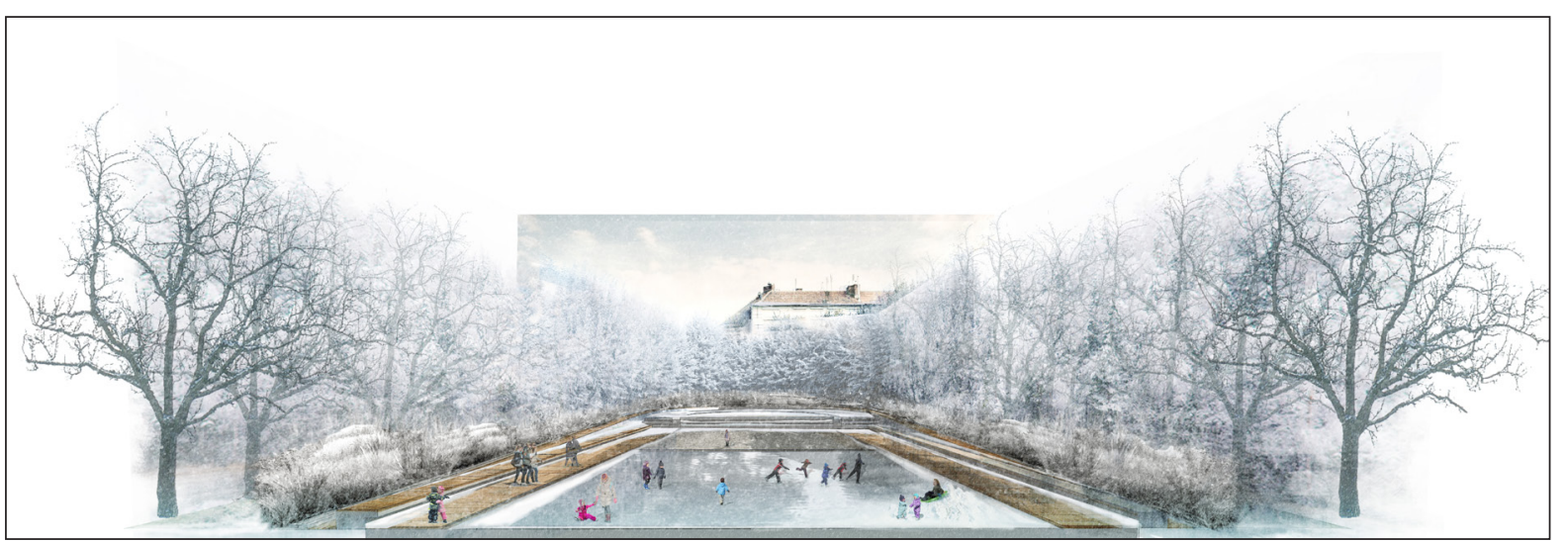

b)

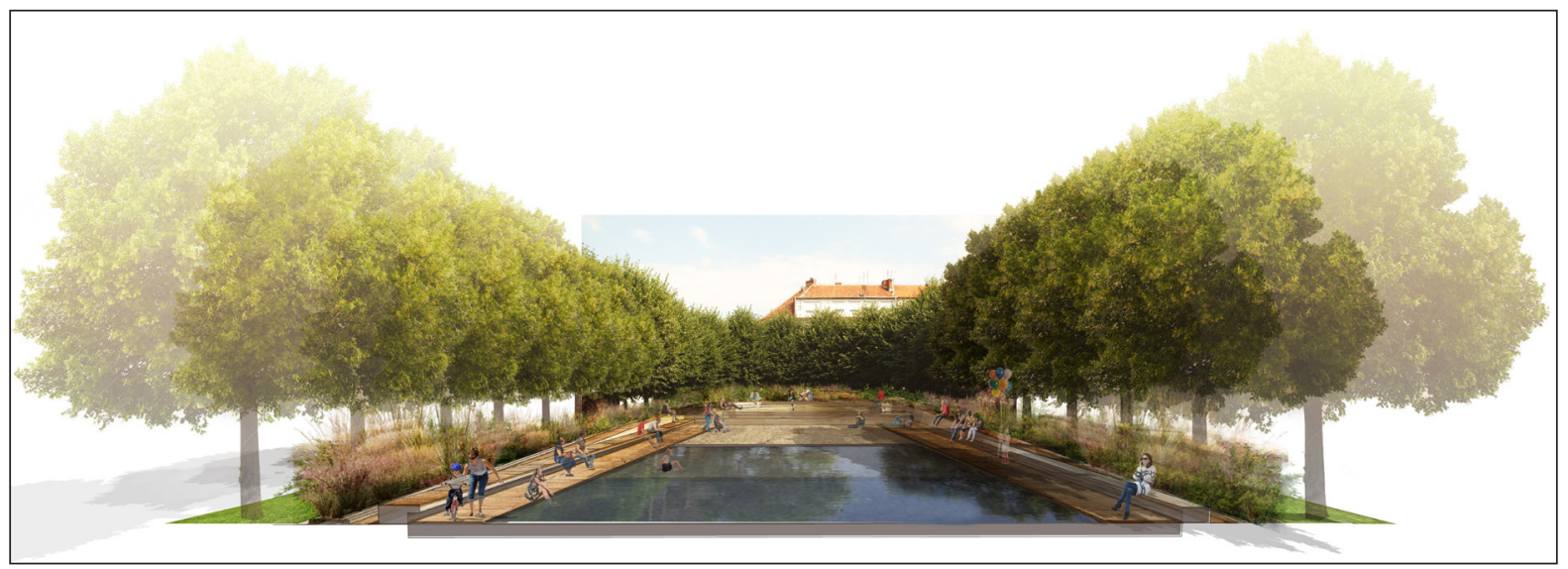

Fig. 12. The reservoir in summer and in winter (visualisation) [Kobierska 2015] 


\section{CONCLUSION}

Assigning high priority to the implementation of strategies related to water management in cities is justified by the rapid pace of urbanisation, which results in an increasing number of sealed areas. Urban areas have become major emitters of pollutants, partly as a result of polluted rainwater runoff. Investing in green areas and modern water management systems improves the quality of life in cities, both by directly enhancing the aesthetic values of places and by being important elements of the eco-hydrological water management. They also contribute to the improved flood safety and increased biodiversity. Moreover, investments in blue and green infrastructure are a response to the current and forecast climate changes, in particular to the potential increase in the frequency of occurrence of torrential rains.

In a city, the hydrographic system of which comprises 5 rivers and numerous channels, with a very high land sealing level, it is indispensable to retain the rainwater running off from such sealed areas. Collecting water in filtration basins, channels and reservoirs will enable to prevent the occurrence of local flooding, and water retention will positively influence the local water balance. Another thing that is important for the surface water quality is the treatment of rainwater discharged from the polluted areas (such as roads or parking lots). The municipal authorities of Wrocław have initiated certain actions that should result in the implementation of rainwater management on site of rainfall as early as in the investment design phase. The major elements of the rainwater management structure in Wrocław are the provisions introduced in the draft of the study of land use conditions and directions that imposes the obligation of sustainable rainwater management. However, as far as the effectiveness of provisions is concerned, the Regulation of the President of Wrocław on rainwater management plays a more important role. It offers a great opportunity to pay more attention to the rainwater retention while realising investments. What is important for sustainable development of the city is for the realisation to take into account the aesthetic values of the place and to co-create a space of high landscape value. Rainwater retention, whether in the form of bio-retention basins overgrown with vegetation or in the form of modern water reservoirs, will complement the city's attempts to receive the European Green Capital Award.

\section{REFERENCES}

1. Burda I. 2010. Woda w kształtowaniu przestrzeni publicznych [w:] Lonens P., Martyniuk-Pęczek J. (red.) Problemy kształtowania przestrzeni publicznych. Wydawnictwo Urbanista, Gdańsk, 168-178.

2. Burszta-Adamiak, 2014. Mechanizmy finansowe gospodarowania wodami opadowymi w miastach. Zrównoważony Rozwój - Zastosowania, 5/2014, Woda w mieście, 59-75.

3. Czaja S., Fiedor B., Graczyk A., Jakubczyk Z. 2001. Podstawy ekonomii środowiska i zasobów naturalnych. C.C.Beck, Warszawa.

4. Drapella-Hermansdorfer A., Ogielski P., Majewicz R. 2004. Zintegrowany system retencjonowania wód opadowych w osiedlu Błękitne w Siechnicach koło Wrocławia [w:] Zeszyty Naukowe Akademii Rolniczej we Wrocławiu (502), Inżynieria Środowiska XIII, Wrocław.

5. Dreiseitl H., Grau D., Ludwig K. H. C. 2001. Planning. Building and Designing with Waterscape. Birkhäuser, Basel.

6. Dubicki A., Dubicka M., Szymanowski M. 2002. Klimat Wrocławia, [w:] Smolnicki K., Szykasiuk M. Informator o stanie środowiska Wrocławia, Dolnośląska Fundacja Ekorozwoju, Wrocław, 9-26.

7. Dubicki A., Dubicka M., Szymanowski M. 2002. Klimat Wrocławia. [w:] Środowisko Wrocławia - Informator 2002, Dolnośląska Fundacja Ekorozwoju, Wrocław, 9-25.

8. Geiger W., Dreiseitl H. 1999. Nowe sposoby odprowadzania wód deszczowych. Poradnik Retencjonowania i infiltracji wód deszczowych do gruntu na terenach zabudowanych. Oficyna wydawnicza Projprzem-EKO, Bydgoszcz.

9. Göransson C.1998. Aesthetic aspects of rainwater management in an urban environment [In:] Rowney A.C., Stahre P., Roesner L.A. (ed.), Sustaining urban water resources in the 21 st century. Proceedings of ASCE Conference, Malmö.

10. Januchta-Szostak A. 2010. Miasto w symbiozie z wodą. Town and Water Symbiosis. Czasopismo Techniczne (14), 95-102.

11. Jawecki B. 2004. Przykład pozytywnego oddziaływania melioracji wodnych na środowisko. Wiadomości Melioracyjne i Łąkarskie, XLVII (1), 28-29.

12. Jormola J. 2004. Restoration of urban streams in connection with rainwater management [in:] Expert Symposium Future Trends \& Challenges of Urban Ecosystem Management, Salzburg.

13. Kobierska K. 2015. Koncepcja projektowa zagospodarowania wód opadowych na pl. Piłsudskiego we Wrocławiu. praca magisterska, Uniwersytet Przyrodniczy we Wrocławiu. 
14. Kołodyński R., 2015. Projektowanie przyjazna gospodarowaniu wodą opadową w krajobrazie miejskim Wrocławia. praca magisterska. Uniwersytet Przyrodniczy we Wrocławiu.

15. Kozłowska E. 2008. Proekologiczne gospodarowanie wodą opadową $\mathrm{w}$ aspekcie architektury krajobrazu. Monografie LXVII, seria Współczesne Problemy Architektury Krajobrazu II, Wydawnictwo Uniwersytetu Przyrodniczego we Wrocławiu, Wrocław.

16. Ładysz J. 2014. Kierunki rozwoju zielonej infrastruktury we Wrocławskim Obszarze Funkcjonalnym. Prace naukowe Uniwersytetu Ekonomicznego we Wrocławiu, 367, 186-195.

17. Nowakowska-Błaszczyk A. 1995. Infiltracja wód opadowych do gruntu jako alternatywa dla tradycyjnych terenów zurbanizowanych. Badania własne [w:] Materiały II Seminarium Instytutu Zaopatrzenia w Wodę i Budownictwa Wodnego, Warszawa, 54-68.

18. Nowakowska-Błaszczyk A. 2004. Projektowanie systemów infiltracyjnych (cz.1). Wnioski z doświadczeń projektowych. Rynek instalacyjny (11), $43-48$.

19. Regulation no. $6541 / 17$ of the President of Wrocław of March 17, 2017 on rainwater management in Wrocław.

20. Schmuck A.1967. Wpływ miasta na opady atmosferyczne (na przykładzie Wrocławia). Przegl. Geod. 12 (20), 3-4.

21. Suligowski Z., Gudelis-Taraszkiewicz K. 2003. Infiltracja do gruntu - alternatywa dla tradycyjnej kanalizacji wód opadowych. Przegląd komunalny (5), $76-77$.

22. Szewrański Sz., Kazak J., Szkaradkiewicz M., Sasik J. 2015. Flood risk factors in suburban area in the context of climate change adaptation policies - Case study of Wroclaw, Poland. Journal of Ecological Engineering, 16(2), 213-18.

23. Uchwała nr XVIII/349/11 Rady Miejskiej Wrocławia $\mathrm{z}$ dnia 17 listopada 2011 r. w sprawie uchwalenia Regulaminu dostarczania wody i odprowadzania ścieków na obszarze Wrocławia. Dziennik Urzędowy Województwa Dolnośląskiego z 26 stycznia 2012 r., poz. 353.

24. Wagner, I., Zalewski, M. 2009. Ecohydrology as a basis for the sustainable city strategic planning focus on Lodz, Poland. Reviews in Environmental Science and Bio/ Technology, 8, 209-217.

25. Waterfall P. 1998. Harvesting Rainwater for Landscape Use. Arizona Department for Water Resources. Tucson, Arizona.

26. Winterbottom D. 2006. Rainwater Harvesting for Landscape Architects. Landscape Architecture. University of Arizona.

27. Wolski P., 1997. Rozwiązania środowiskowe na terenach zakładów przemysłowych na przykładzie zakładu tytoniowego firmy RJR Tobacco-Poland [w:] Richling A., Lechnio J., Malinowska E. (red.) Zastosowanie ekologii krajobrazu w ekorozwoju, materiały konferencji Zakładu Geoekologii Wydziału Geografii i Studiów Regionalnych Uniwersytetu Warszawskiego oraz Polskiej Agencji Ekologii Krajobrazu, Warszawa. 